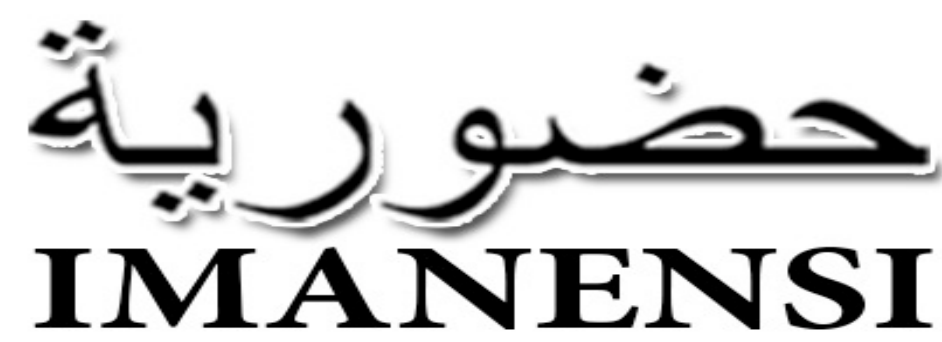

(Jurnal Ekonomi, Manajemen, dan Akuntansi Islam)

Vol 4, No 1, Maret 2019, Hlmn. 23-42

\title{
Akuntansi syariah dalam metafora haji
}

Jurana

a Universitas Tadulako, 1. Soekarno-Hatta KM.9,

Palu, Sulawesi tengah, Indonesia 94148

1*jurananurdin@gmail.com; jurananurdin@untad.ac.id

doi: 10.34202/imanensi.4.1.2019.23-42.

\section{Abstrak}

Penelitian ini bertujuan untuk memberikan gambaran terkait berbagai nilai akuntabilitas yang seharusnya ada dalam akuntansi syariah. Penelitian ini dilakukan dengan menggunakan akuntabilitas dalam metafora haji. Hal ini dikarenakan salah satu bentuk dari akuntabilitas individu dan sosial bangsa indonesia kepada Allah SWT ialah dengan melaksanakan ibadah haji yang merupakan rukun Islam yang kelima. Hasil penelitian menunjukkan bahwa nilai yang seharusnya ada dalam akuntansi syariah yang juga ada dalam haji ialah nilai motivasi, ikhtiar, nilai pengorbanan, introspeksi diri, komitmen bekerja keras, dan pantang berputus asa, penyerahan diri dan pengendalian diri.

Kata Kunci: Akuntabilitas; Haji; Akuntansi Syariah.

\section{Abstract}

This study aims to provide an overview of the various values of accountability that should be present in Islamic accounting. This research was conducted using accountability in the hajj metaphor. This is because one of the forms of individual and social accountability of the Indonesian nation to Allah SWT is by performing the Hajj which is the fifth pillar of Islam. The results showed that the values that should be present in Islamic accounting which also existed in the Hajj were values of motivation, effort, sacrifice value, self-introspection, commitment to work hard, and abstinence from despair, surrender and selfcontrol.

Keywords: Accountability; Hajj; Islamic Accounting.

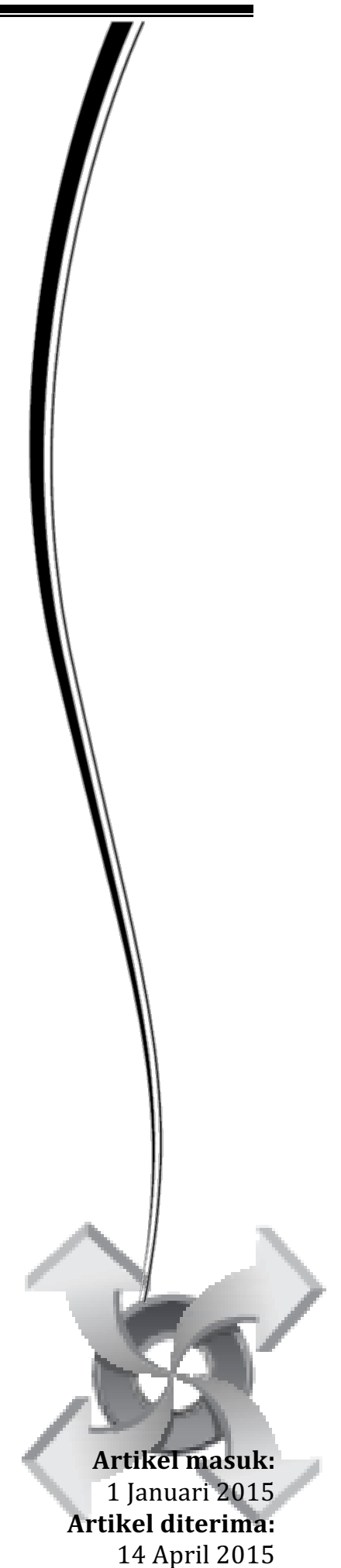

This is an open access article under the CC-BY-SA license. 
Akuntansi syariah menurut Triyuwono (2009) merupakan seni dan ilmu meracik informasi akuntansi yang berfungsi sebagai doa dan dzikir untuk memenuhi kebutuhan ekonomi, mental dan spiritual manusia dalam rangka beribadah dan kembali pada Tuhan dengan jiwa yang suci dan tenang. Akuntansi Syariah yang banyak tumbuh saat ini, telah memberikan nilai pencerahan pada ilmu akuntansi, hal ini disebabkan karena syariahnya menempatkan setiap pekerjaan dalam sebuah organisasi maupun individu dengan nilai "ibadah" (Adlan : 2009). Ibadah yang dilakukan individu dalam interaksi sosial masyarakat akan berubah pada ibadah sosial, dan ibadah sosial akan membentuk individu-individu yang beribadah sehingga tujuan dasar dari akuntansi sebagai alat penyampai informasi benar-benar memiliki nilai akuntabilitas yang tinggi. Akuntabilitas yang tinggi inilah merupakan dasar dari akuntansi syariah yang sesungguhnya.

Berbagai bentuk ibadah yang diproksikan dalam berbagai pekerjaan yang bertujuan memperoleh keridhaanNya itulah merupakan bentuk akuntabilitas kita kepada Sang Khalik yang menciptakan kita sebagai Khalifah dimuka bumi. Manusia yang didalamnya merupakan para stockholder dan akuntan adalah wakil Allah (Khalifatullah fi al-ard) yang memiliki kewajiban-kewajiban tertentu kepada "Sang khalik". Berbagai kewajiban yang diberikan kepada manusia sudah seharusnya mereka patuhi dan laksanakan serta mempertanggungjawabkannya kepada "Sang Khalik". Sebagaimana dalam Firman Allah SWT (QS (2):30) dibawah ini:

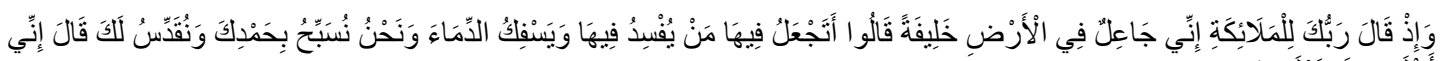

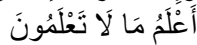

Artinya: "Ingatlah ketika Tuhanmu berfirman kepada para malaikat: "Sesungguhnya Aku hendak menjadikan seorang khalifah di muka bumi". Mereka berkata: "Mengapa Engkau hendak menjadikan (khalifah) di bumi itu orang yang akan membuat kerusakan padanya dan menumpahkan darah, padahal kami senantiasa bertasbih dengan memuji Engkau dan menyucikan Engkau?" Tuhan berfirman: "Sesungguhnya Aku mengetahui apa yang tidak kamu ketahui"

Ayat diatas menjelaskan bahwa manusia dimuka bumi ini diciptakan oleh Allah SWT sebagai khalifah yaitu entitas yang melekat sebagai mahluk Tuhan yang paling sempurna diantara mahluk lainnya. Hal ini disebabkan karena manusia diciptakan dengan potensi yang berpeluang dalam menciptakan peradaban dengan iman melalui keyakinan religius yang dianutnya. Keyakinan tersebut mampu mengkontribusikan apa yang dia punya melalui sebuah pengetahuan dalam mencari tau tentang kebenaran menuju kebenaran mutlak yaitu Allah SWT sebagai tujuan hidupnya, yakni mengabdi kepadaNya dan meniadakan posisi lain atau menyetarakan.

Manusia sebagai khalifah fi al-Ardhi sudah selayaknya mengabdi pada tujuan tauhid di muka bumi ini sebagai akuntabilitasnya kepada sang Khalik. Menurut Syekh Syaukat Hussain (1996) ada beberapa konsep yang harus dilaksanakan manusia sebagai khalifatuh fi al-Ardhi, antara lain : manusia hanyalah bertindah sebagai pengelola (administrator) dan manusia tidak memegang posisi ini menurut haknya sendiri tanpa mempertimbangkan hak orang lain, manusia harus mengelola sesuai dengan arahan-arahan yang diberikan Tuhan, selama menjalankan kekuasaan, hendaknya manusia memenuhi tujuan maksud dan tujuan Tuhan, manusia harus menjalankan kekuasaan dengan batas-batas yang digariskan oleh Tuhan, dan setiap manusia yang memegang kekuasaan kendaknya bertanggung jawab atas segala tindakan yang diambil. Diperlukan aspek ritual yang mengintegralkan pribadi dengan kelompok yang berkebangsaan dengan mendasarkan pada pondasi iman, ilmu, dan amal.

Salah satu bentuk dari akuntabilitas individu dan sosial bangsa indonesia kepada Allah SWT adalah dengan melaksanakan ibadah haji. Perintah melaksanakan ibadah haji ini telah diamanahkan pada seluruh umat islam didunia sebagaimana yang tercantum pada Al-qur'an dan Al Hadits yang merupakan pedoman hidup umat islam diseluruh dunia. Secara spiritual, ibadah ini memilki daya pikat yang luar 
biasa. Berbagai ritual-ritual yang ada dalam pelaksanaan haji terkandung nilai-nilai yang dapat dijadikan sandaran dalam membangun akuntansi syariah, meskipun ibadah haji itu sendiri merupakan akuntabilitas umat islam kepada sang khalik. Nilai-nilai tersebut seperti motivasi, pengorbanan, keikhlasan, ketaatan, introspeksi diri, komitmen bekerja keras, pantang berputus asa dan pengendalian diri.

\section{HASIL DAN PEMBAHASAN}

\section{Haji Sebagai Bentuk Akuntabilitas Umat Islam dan Kaitannya dalam Akuntansi}

Syariah. Haji adalah ibadah yang istimewa jika dilihat dari beratnya persyaratan, prosesi ibadah dan reward yang dijanjikan oleh Sang Pemilik Kehidupan, Allah SWT. Karenanya sangat masuk akal jika haji ditempatkan sebagai rukun Islam yang ke lima. Saking istimewanya setiap tahun jutaan umat muslim dari seluruh dunia rela menghabiskan biaya yang besar, meluangkan waktunya dan meninggalkan segala kenyamanan dikampung halamannya selama berhari-hari terlebih untuk berkumpul di tanah haram melaksanakan rukun-rukun haji yang diperintahkan Sang Khalik. Tidak terkecuali jamaah haji dari Indonesia yang jumlahnya kurang lebih mencapai 200-ribuan orang per tahunnya, Jumlah yang sangat besar. Haji merupakan rukun islam paripurna, suatu tuntunan untuk beribadah ke Baitullah sesuai dengan firman Allah SWT, "Dan sempurnakanlah haji dan umrah untuk Allah"

Ibadah haji ibarat kawah candradimuka untuk melahirkan orang-orang saleh, jujur, berintegritas dan mampu menjadi teladan bagi yang lain. Dapat kita lihat, hampir semua prosesi dalam ibadah haji adalah penggemblengan spiritual yang berkaitan dengan peningkatan kesalehan individu dan kesalehan sosial jamaah haji. Kewajiban ibadah haji berbeda dengan kewajiban ibadah dengan lainnya, karena ibadah haji ditekankan bagi orang-orang yang mampu, yaitu sehat jasmani dan rohani serta mempunyai perbekalan yang cukup untuk pulang dan pergi. Artinya, jika seseorang telah memiliki kemampuan menunaikan ibadah haji namun tidak mau melaksanakannya dengan berbagai alasan maka orang tersebut dianggap belum menyempurnakan keislamannya. Jadi apabila saat ini kita telah memiliki kemampuan untuk mendaftar haji dan memiliki tubuh yang sehat untuk melaksanakan ibadah haji maka sebaiknya kita menyegerakan untuk berhaji.

Terkait dengan Kemampuan individu, ada beberapa individu yang memiliki kemampuan finansial namun tidak memiliki kemampuan fisik dan kemampuan spiritual, ada juga yang memiliki kemampuan jasmani dan spiritual namun tidak memiliki kemampuan finansial, dan adapula yang memiliki kemampuan finansial, spiritual namun tidak memiliki kemampuan fisik. Individu-individu tersebut, tidak dapat melakukan ibadah haji jika tidak memiliki semua kemampuan yang disyariahkan tersebut. Ironisnya, saat ini terdapat beberapa individu yang sudah memiliki berbagai kemampuan tersebut namun belum termotivasi untuk melaksanakan Ibadah Haji. Individu-individu tersebut terkadang lebih memprioritaskan untuk mengumpulkan dan memperbanyak material-materialnya dan mengulur-ulur waktu untuk menjalankan Ibadah haji. Orang seperti inilah yang penulis maksud belum bisa memberikan akuntabilitasnya kepada sang Khalik.

Manfaat ibadah Haji adalah sebagai pembersihan jiwa dan Hubungan Allah dan Rasul-Nya. Jadi, Ibadah adalah realisasi keimanan kepada Allah, dan tanda penyerahan diri kepada-Nya. Orang yang menjadikan ibadah sebagai jiwa aktifitas pengisi waktunya, ia akan tetap tenang hatinya, tentram jiwanya dalam menghadapi situasi dan kondisi kehidupannya karena ia menyerahkan diri sepenuhnya kepada Allah SWT, dengan melaksanakan segala perintah-Nya dan menjauhi segala laranganNya, sesuai dengan kemampuannya. Karena hal inilah sehingga penulis katakan bahwa ibadah haji merupakan wujud akuntabilitas individu kepada sang Khalik. Demikian pula halnya akuntansi syariah sebaiknya dibangun dengan pondasi keimanan kepada Allah SWT sehingga aktivitas akuntansi syariah yang dijalankan adalah ibadah sebagai bentuk akuntabilitas para akuntan yang menjadikan tenang hatinya dan tentram jiwanya dalam menghadapi berbagai situasi dan kondisi apapun.

Meskipun islam mengatur bahwa kewajiban melaksanakan ibadah haji adalah bagi mereka yang mampu dalam artian mampu memikul beban biaya perjalanan, mampu fisik dan mampu segalanya. namun banyak orang islam indonesia yang 
berupaya keras demi dapat menjalankan rukun islam yang kelima ini. Dapat dikatakan bahwa tingginya angka jamaah haji Indonesia merupakan indikasi dari dua hal penting. Pertama, meningkatnya ketakwaan dan keshalehan dengan memenuhi rukun Islam kelima. Sebuah bukti bahwa akuntabilitas spiritual individu semakin membaik. Kedua, hal itu menunjukkan pula membaiknya kemampuan ekonomi (Vredenbregt, 1997: 21), sebab, untuk menunaikan ibadah haji diperlukan biaya yang sangat tinggi. Bukti wujud akuntabilitas atas materi yang dimiliki individu tersebut. Firman Allah SWT (QS (2):196):

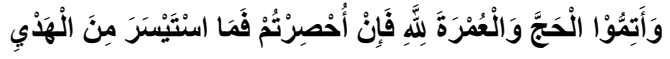

Artinya:" Dan sempurnakanlah ibadah haji dan umrah karena Allah. Apabila kamu terkepung (terhalang oleh musuh atau sakit), (sembelihlah) kurban yang mudah didapat..."

Akuntansi syariah yang berlandaskan pada Al-quran dan As-Sunnah memandang bahwa tujuan dasar dari akuntabilitas dalam prakteknya bukanlah sekedar akuntabilitas yang bersifat vertikal (hablum min al-Allah) tapi juga sebagai akuntabilitas yang bersifat horisontal, dapat dipertanggungjawabkan kepada Allah SWT (hablum min al-nas). Hal ini karena manusia yang termasuk didalamnya para stockholder dan akuntan adalah merupakan wakil Allah (Khalifatullah fi al-ard) yang memiliki kewajiban-kewajiban tertentu kepada "Sang khalik" dan sudah seharusnyalah mereka memberikan pertanggungjawaban kepada "Sang Khalik". Firman Allah SWT (QS (2):30):

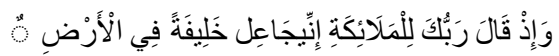

Artinya: "Ingatlah ketika Tuhanmu berfirman kepada para malaikat: Sesungguhnya Aku hendak menjadikan seorang khalifah di muka bumi".

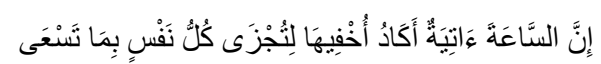

Artinya: "Sesungguhnya saat (hari kiamat) akan datang. Aku dengan sengaja merahasiakan (waktu)nya. Agar setiap jiwa diberi balasan (dan ganjaran) sesuai dengan hasil usahanya". (QS. (20):15)

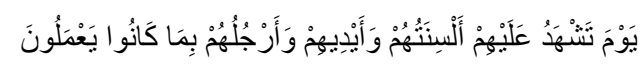

Artinya: "Pada hari itu yang menjadi saksi atas mereka adalah lidah, tangan dan kaki mereka, menyangkut apa yang dahulu mereka lakukan".(Q.S (24):24)

Dari berbagai penjelasan diatas, jelaslah bahwa berhaji merupakan akuntabilitas umat islam didunia pada umumnya dan indonesia pada khususnya. Untuk itu setiap individu haruslah memiliki upaya untuk dapat melaksanakan ibadah haji sebagai akuntabilitasnya kepada Allah SWT sebagaimana yang telah diamanahkan dalam Al-qur'an dan Al-Hadits. Implikasi dalam akuntansi yaitu bahwa individu yang terlibat dalam praktik bisnis harus selalu melakukan pertanggungjawaban apa yang telah diamanahkan dan diperbuat kepada pihak-pihak yang terkait dalam rangka beribadah dan kembali pada Tuhan dengan jiwa yang suci dan tenang. Dalam hal ini, wujud akuntabilitasnya yaitu dalam bentuk laporan akuntansi yang amanah dan suci.

Akuntabilitas Dalam Upaya Menuju PanggilanNya Berhaji (Nilai Motivasi bagi Akuntansi syariah). Berhaji merupakan ibadah memediasi pertemuan manusia dengan sang khalik dan merupakan kewajiban bagi setiap umat islam yang memiliki kemampuan untuk menjalankannya. Kemampuan tersebut berupa kemampuan dalam hal sehat jasmani dan rohani serta mempunyai perbekalan yang cukup untuk pulang dan pergi (kemampuan materi dan fisik). seperti yang dijelaskan Allah SWT dalam firmanNya:

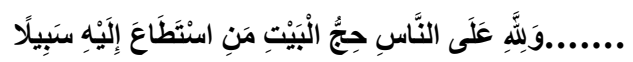

Artinya: “.....Mengerjakan haji adalah kewajiban manusia terhadap Allah, yaitu (bagi) orang yang mampu mengadakan perjalanan ke Baitullah...” (QS (3): 97) 
Untuk itu, berhaji merupakan salah satu bentuk pertanggungjawaban (akuntabilitas) umat islam yang memiliki kemampuan tersebut. Banyak diantara umat islam yang berkeinginan untuk berhaji, namun tidak memiliki salah satu dari kemampuan tersebut. Sebaliknya ada pula yang memiliki kemampuan-kemampuan tersebut namun tidak berniat untuk menjalankannya, individu seperti ini akan dimintai pertanggungjawabannya kepada Sang Khalik. Kemampuan ini juga terkait dengan kemampuan individu dalam melaksanakan penggemblengan spiritual dan fisiknya dalam menghadapi berbagai ujian dalam proses sebelum pelaksanaan, saat pelaksanaan dan sesudah pelaksanaan haji tersebut.

Kemampuan fisik dan kemampuan materi merupakan upaya (ikhtiar) yang harus dilakukan bagi setiap individu. Ikhtiar adalah usaha seorang individu untuk mencapai tujuan atau keinginannya. Untuk itu, sudah menjadi kewajiban bagi setiap individu untuk melakukan ikhtiar agar memiliki kemampuan fisik dan kemampuan materi. Seberapa besar upaya seseorang tersebut, Sang Khalik akan mengetahuinya. Selain ikhtiar setiap umat islam juga memiliki hak untuk berdoa kepada Sang Khalik agar keinginan dan tujuan berhaji dapat tercapai. Demikian pula halnya dalam konteks aplikasi akuntansi, upaya-upaya (ikhtiar) untuk melakukan dekonstruksi terhadap bangun akuntansi modern menuju pada bangun akuntansi (alternatif) yang lebih baik dalam upaya agar senantiasa kembali kepada fitrah yang seharusnya.

Setiap umat islam, memiliki akuntabilitas untuk memotivasinya dirinya dalam melaksanakan ibadah haji bagi yang telah memiliki kemampuan. Tentunya dalam hal ini adalah motivasi yang berbasis religiusitas. Menurut (M.Sulthoni, Muhlisin, \& Mutho'in, 2012) motivasi haji berbasis religiusitas merupakan spirit yang terkandung dalam individu yang melaksanakan haji, pure atau murni semata-mata hanya karena ingin mendekatkan diri kepada Allah SWT, lebih menguatkan iman dan untuk menyempurnakan rukun islam yang kelima. Demikian pula dalam hal akuntansi, motivasi yang berbasis religiusitas haruslah menjadi sandaran dalam membentuk akuntansi syariah sehingga spirit yang terkandung dalam akuntansi syariah murni semata-mata untuk mencapai ridhoNya.

Berdasarkan penelitian yang dilakukan (Putuhena \& Saleh, 2007) mengungkapkan terdapatnya keyakinan kolektif dalam suatu kalangan bahwa harta tidak hanya sekedar digunakan untuk memenuhi kebutuhan jasmani, namun juga kebutuhan rohani. Jika ada seseorang muslim yang telah memiliki kemampuan (harta), maka uang tersebut harus digunakan untuk naik haji. Atau sebaliknya, naik haji digunakan untuk memotivasi dinya untuk dapat bekerja lebih keras dan bersikap hemat. Dari hal tersebut, dapat disimpulkan bahwa terdapat terdapat dua konsep kaum santri dalam memandang haji. Yaitu: pertama, berkah. Seluruh aktivitas hidup sesorang dianggap berkah karena dapat melaksanakan haji secara langsung untuk menziarahi Tanah Suci. Kedua, peningkatan kualitas ekonomi. Dalam hal ini haji berfungsi untuk memotivasi pelakunya dalam pengembangan kualitas ekonomi, seperti yang disimbolkan dalam ritual sa'i. Dalam konteks ini, pelaksanaan ibadah haji akan mempertemukan dan memperkuat antara ide kesholehan individu dengan keharusan materi.

Seperti pada penjelasan sebelumnya bahwa haji merupakan rukun islam kelima, namun realitas yang terjadi selama beberapa waktu muncul kata candaan bahwa haji bisa jadi merupakan rukun islam kedua atau rukun islam ketujuh. Mengapa demikian? Dikatakan rukun islam kedua, hal ini disebabkan karena beberapa individu yang menjalankan ibadah haji dengan tujuan agar memperoleh derajat yang tinggi dalam masyarakat tanpa menjalankan rukun islam kedua (sholat), ketiga (puasa) dan keempat (zakat). Bagi mereka sholat, puasa dan zakat tidaklah penting. Yang penting bagi mereka setelah menyatakan keislamannya dengan bersyahadat, mereka bisa pergi haji.

Namun adapula beberapa realitas yang terjadi yang menjadikan haji sebagai rukun islam yang ketujuh dengan kata lain menambahkan rukun yang lain dulu yaitu setelah zakat, tidak langsung menunaikan ibadah haji namun rukun kelimanya yaitu rumah, dan rukun keenam yaitu mobil, baru kemudian rukun ke tujuh pergi berhaji. Padahal sesungguhnya urutan rukun islam dimulai dari bersyahadat, 
mengerjakan sholat, berpuasa, menunaikan zakat, kemudian melaksankan ibadah haji (Mustofa, 2009).

Selain kasus-kasus diatas, beberapa tahun belakangan ini ada trend yang sedikit membuat saya agak bingung dengan kebaradaannya. Yaitu haji kredit dan haji arisan. Apakah hal ini dibenarkan? Terdapat pertentangan yang substansial dengan hal ini. Haji kredit merupakan cara baru dalam upaya menunaikan ibadah haji yaitu melalui pembiayaan dari bank. Melaksanakan haji dengan cara kerdit atau berhutang tidaklah dibenarkan dalam syariat islam karena hal tersebut akan memberatkan dirinya sendiri dan digolongkan dalam kategori belum mampu. Hal ini disebabkan karena orang yang berhutang sampai meninggalpun akan dimintai pertanggungjawabannya sedangkan tidak berhaji dalam keadaan belum mampu tidak akan dimintai pertanggungjawaban apapun oleh Allah SWT.

Istilah haji kredit atau haji yang melalui pembiayaan bank (dana talangan) dibenarkan jika itu merupakan upaya seseorang mencari jalan untuk memotivasi dirinya mengumpulkan dana dalam rangka memperoleh antrian nomor porsi haji pada haji reguler, asalkan saat pelaksanaan haji tiba kewajiban terhadap kredit atau pinjaman kepada bank tersebut telah diselesaikan/dilunasi. Seperti yang kita ketahui, saat ini diindonesia untuk dapat berangkat haji, terlebih dahulu seseorang harus memperoleh nomor porsi haji dengan cara menyetorkan dana yang jumlahnya sesuai dengan aturan dalam kementrian agama republik indonesia ${ }^{1}$, kemudian akan menanti melalui antrian dalam kurun waktu beberapa tahun. Saat penantian atau masa tunggu inilah seseorang mengupayakan atau menyisihkan dananya untuk melunasi kewajiban atau dana talangan yang telah diambil kepada suatu bank tertentu dan untuk melakukan pelunasan biaya haji sesuai dengan tarif yang berlaku. Agar saat giliran nomor porsi antriannya telah tiba untuk diberangkatkan, maka tidak ada lagi kewajiban yang harus dipenuhinya dalam rangka pelaksanaan hajinya.

Haji arisan yaitu haji yang dijalankan dimana dana yang diperolehnya berasal dari penyelenggaraan arisan dari suatu komunitas masyarakat. Sama seperti haji kredit diatas, haji arisan ini juga tidaklah dibenarkan jika tiba saat pelaksanaan berhaji namun belum atau tidak berkemampuan menyelesaikan kewajibannya untuk membayar iuran arisan tersebut. Namun jika arisan yang diperolehnya hanyalah untuk tujuan mengumpulkan dana dan berkeyakinan dapat memenuhi angsuran arisan demi memperoleh nomor porsi haji maka hal ini adalah upaya (ikhtiar) orang tersebut dalam mengumpulkan dananya untuk dapat menjalankan ibadah haji ke Baitullah. Asalkan setelah antrian nomor porsi hajinya telah tiba orang tersebut telah menyelesaikan segala kewajiban-kewajiban arisan yang diikutinya dan menyelesaikan biaya pelunasan haji. Dengan demikian, dana haji yang diperoleh dari kredit (dana talangan) dan arisan dibenarkan jika kredit atau arisan tersebut ditujukan untuk membangkitkan kemampuan diri sendiri dengan tidak menyimpan potensi masalah dibelakangnya. Sama seperti sebuah motto :" menyelesaikan masalah tanpa masalah" (dalam hal ini masalah mengumpulkan dana atau simpanan untuk penyelenggaraan haji). Firman Allah SWT:

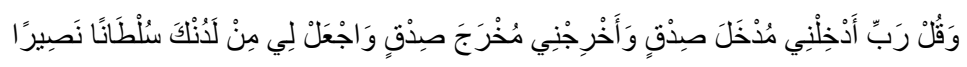

Artinya: "Dan katakanlah: "Ya Tuhan-ku, masukkanlah aku secara masuk yang benar dan keluarkanlah (pula) aku secara keluar yang benar dan berikanlah kepadaku dari sisi Engkau kekuasaan yang menolong". (QS (17):80)

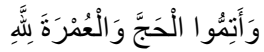

Artinya: "Dan sempurnakanlah ibadah haji dan umrah karena Allah semata...."(QS (2): 196)

\footnotetext{
${ }^{1}$ Tahun 2015 ini pemerintah menetapkan bahwa untuk memperoleh nomor porsi haji harus memiliki saldo minimal Rp. 25.100.000,- pada suatu bank tertentu. Selanjutnya diatur dalam peraturan menteri agama republik indonesia..
} 


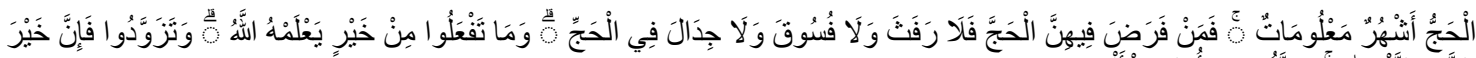

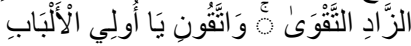

Artinya: “(Musim) haji adalah beberapa bulan yang dimaklumi, barangsiapa yang menetapkan niatnya dalam bulan itu akan mengerjakan haji, maka tidak boleh rafats, berbuat fasik dan berbantah-bantahan di dalam masa mengerjakan haji. Dan apa yang kamu kerjakan berupa kebaikan, niscaya Allah mengetahuinya. Berbekallah, dan sesungguhnya sebaik-baik bekal adalah takwa dan bertakwalah kepada-Ku hai orang-orang yang berakal". (QS (2): 197)

Saat akan melaksanakan ibadah haji, atau disaat niat seseorang bertekat untuk berhaji terkadang ada ujian-ujian yang akan dihadapkan ke orang tersebut, berbagai masalah kerap terjadi yang memicu sesorang untuk menarik kembali dana haji yang telah terkumpul atau membatalkan keberangkatan untuk berhaji. Namun hal tersebut merupakan proses penggemblengan yang diajarkan Sang Khalik kepada hambanya. Ujian - ujian tersebut akan menjadikan atau membentuk individu untuk menjadi lebih kuat dan lebih dekat kepadaNya. Seseorang yang tidak dapat melalui proses ini, maka akan serta merta membatalkan niat awalnya. Berbagai godaan syetan yang menyenangkan kerap datang dalam diri seseorang yang bertujuan menjerumuskan orang tersebut kedalam kenistaan. Namun individu yang bisa melewati proses penggemblengan atau tantangan ini sungguh luar biasa yang nantinya menjadikan dirinya menghargai dan menjaga hajinya kelak.

Terkait dengan akuntansi syariah, maka nilai-nilai yang sebaiknya digunakan dalam membangun akuntansi syariah dalam hal akuntabilitas menuju PanggilanNya (berhaji) adalah memotivasi diri untuk berikhtiar membentuk akuntansi syariah yang berbasis religiusitas agar spirit yang terkandung dalam akuntansi syariah murni semata-mata untuk mencapai ridhoNya. Bukan sekedar untuk memenuhi kepentingan golongan atau kelompok dalam hal memperoleh derajat yang tinggi dalam masyarakat seperti yang ada pada akuntansi konvensional saat ini. Sehingga menyebabkan kelompok atau golongan yang kuat makin kuat dan yang lemah makin tertindas.

\section{Akuntabilitas Saat Memenuhi PanggilanNya Berhaji (Nilai Pengorbanan, Introspeksi Diri, Komitmen Bekerja Keras, Pantang Berputus Asa Bagi Akuntansi Syariah). Prosesi Ibadah haji adalah prosesi pensucian jiwa manusia dan perpaduan kemampuan hati, fisik dan harta. Dalam haji kita diajarkan untuk berkorban dan berserah diri kepada Allah SWT yang seharusnya kita lakukan dan merupakan wujud akuntabilitas kita kepada sang khalik. Menurut Agus Mustofa, Ketika kita bisa menjalankan ibadah haji dalam keadaan berkorban, berada dalam kesempitan, namun bisa melaksanakan adalah suatu hal yang luar biasa. Berbeda halnya jika orang menjalankan ibadah haji ketika dalam kondisi lapang, tentunya rasa pengorbanannya jauh berkurang. Rasa pengorbanan itulah yang memperoleh keridhaan Allah SWT dengan kualitas yang tinggi. Seperti pada Firman Allah (QS (2):207):

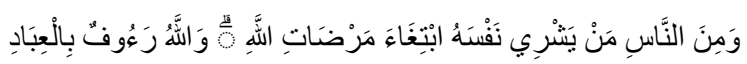

Artinya: "Dan di antara manusia ada orang yang mengorbankan dirinya karena mencari keridhaan Allah; dan Allah Maha Penyantun kepada hamba-hambaNya."

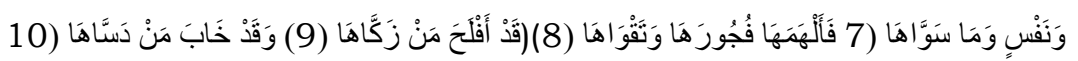

Artinya: "Demi jiwa dan penyempurnaan (ciptaannya), maka Allah mengilhamkan kepada jiwa itu (jalan) kefasikan dan ketakwaannya, sesungguhnya 
beruntunglah orang yang menyucikan jiwa itu, dan sesungguhnya merugilah orang yang mengotorinya. (QS (91): 7-10).

Saat pelaksanaan ibadah haji, seorang yang berhaji harus mengetahui dan menjalankan rukun haji. Rukun haji merupakan hal-hal atau amalan-amalan yang wajib dikerjakan dalam proses pelaksanaan ibadah haji. Amalan-amalan tersebut, tidaklah bisa ditinggalkan dan tidak dapat digantikan dengan membayar dam (denda). Seorang calon haji yang tidak mengerjakan salah satu dari rukun haji maka hajinya tidaklah sah baik itu disengaja, alpa, atau tidak tahu.

Dalam hal rukun haji, terdapat perbedaan pendapat yang dikemukakan oleh beberapa ulama. Menurut imam syafi'i rukun haji dibagi menjadi lima, yaitu ihram, wukuf di Arafah, thawaf, sa'i serta tahallul. Sementara menurut imam Hanafi, rukunhaji ada dua yaitu wukuf di Arafah dan thawaf Ifhadah. Sedangkan imam Malik dan Imam Hambali mengatakan rukun haji ada empat, yaitu: Ihram, Wukuf di Arafah, thawaf ifadhah, dan sa'i. Selain rukun haji, hal lain yang harus diketahui adalah wajib haji. Wajib haji merupakan amalan yang semestinya dilaksanakan ketika melakukan ibadah haji. Namun, amalan ini ketika ditinggalkan tidak menyebabkan hajinya rusak atau batal. Hajinya akan tetap sah, namun diharuskan membayar dam (denda).

Seperti halnya rukun haji, wajib haji juga terdapat beberapa pendapat ulama yang berbeda. Imam Syafi'i mengemukakan bahwa wajib haji ada lima. Pertama, ihram (memakai pakaian berwarnah putih dan tidak berjahit bagi laki-laki) dari miqat . Orang indonesia mulai melakukan miqat di daerah bernama Yalamlam. Kedua, bermalam musdalifah. Ketiga, melontar jumrah di Mina. Keempat, bermalam di Mina. Kelima, Thawaf Wada'(thawaf perpisahan). Menurut Imam Hanafi juga ada lima. Yaitu, Sa'i (berlari kecil antara bukit shafa dan Marwah), Mabit (bermalam) di Musdalifah, melempar jumrah di Mina, Tahallul (mencukur atau memotong rambut) dan thawaf Wada'.

Sementara Imam Malik mengemukakan wajib haji adalah berihram dari miqat makani, membaca talbiyah, thawaf qudum, mabit di Mina pada malam-malam melontar jumrah, menunaikan sholat jamak di Arafah (zuhur dan ashar) dan di Musdalifah (magrib dan isya). Sedangkan Imam Hanbali berpendapat bahwa wajib haji ada tujuh. Yaitu berihram dari miqat, mabit di Musdalifah, melontar jumrah, mabit di Mina, thawaf Wada', Wukuf di Arafah, dan Tahallul (mencukur atau memotong rambut).

Sebagaimana yang telah penulis jelaskan diatas bahwa haji merupakan proses penggemblengan diri, khususnya saat melaksanakan ibadah haji. Banyak hal-hal dan ujian-ujian yang akan kita hadapi. Pelaksanaan ibadah haji yang mencapai lebih dari 40 hari, merupakan perjuangan tersendiri dalam memanajemeni. Misalnya saja, tempat pemondokan yang jauh, catering yang terkadang bermasalah (bisa jadi tidak sesuai selera) antrian dalam mendapatkan berbagai kebutuhan pokok, transportasi yang tidak selalu tersedia, antrian untuk ke kamar kecil dan lain sebagainya. Namun pada setiap kesulitan-kesulitan itulah terdapat berbagai pelajaran berharga yang terkandung dalam hikmah haji.

Perjuangan - perjuangan dalam proses pelaksanaan ibadah haji tersebut mengingatkan seseorang akan perjuangan nabi Ibrahim as dan keluarganya dengan penuh kesabaran, ketaatan, keikhlasan, dan pengorbanan dalam menghadapi berbagai ujian dari Allah SWT. Sehingga kita benar-benar merasakan berbagai hikmah dalam napak tilas perjalanan ibadah haji. Dengan demikian, tiap prosesiprosesi haji memiliki filosofi dan makna yang mendalam. Hal inilah yang menjadikan ibadah haji begitu istimewa. Sehingga bagi yang sudah menunaikannya diberikan gelar sebutan haji. Penyebutannya secara langsung, baik nama maupun pelaksanaannya dalam Al-quran.

Beberapa Filosofi Pelaksanaan Amalan Haji

Wukuf di Padang Arafah. Arafah (Jabal Rahmah) merupakan suatu tempat dimana Allah SWT mempertemukan Nabi Adam dan Hawa setelah mereka diturunkan dari Surga (Taman Firdaus) dan berpisah selama 100 tahun. Mereka dipertemukan untuk memulai adanya kehidupan di Dunia dan untuk menjadi khalifah di muka 
bumi. Dari sinilah kehidupan manusia dimulai hingga terciptalah keturunan Nabi Adam yang menyebar menjadi suku dan negara. Firman Allah SWT (QS (2):30):

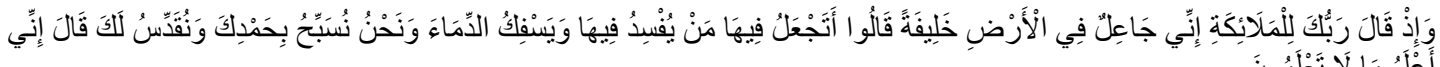

Artinya: "Ingatlah ketika Tuhanmu berfirman kepada para malaikat: "Sesungguhnya Aku hendak menjadikan seorang khalifah di muka bumi". Mereka berkata: "Mengapa Engkau hendak menjadikan (khalifah) di bumi itu orang yang akan membuat kerusakan padanya dan menumpahkan darah, padahal kami senantiasa bertasbih dengan memuji Engkau dan menyucikan Engkau?" Tuhan berfirman: "Sesungguhnya Aku mengetahui apa yang tidak kamu ketahui"

Wukuf memiliki makna diam atau berhenti, melepaskan dari segala aktifitas yang sering dilakukan dan berhenti memikirkan dunia. Saat inilah 'perenungan kehidupan' yang merupakan puncak perjalanan haji seseorang. Seseorang yang berwukuf sebaiknya berzikir, berdoa, dan bersyukur atas segala yang telah dilaluinya substansinya yaitu introspeksi diri atas apa yang telah dilalui sepanjang usia. Rasulullah saw bersabda bahwa 'tidak sah haji tanpa wukuf di Arafah' ditempat ini pula beliau menerima wahyu terakhir dari Allah SWT. Waktu pelaksanaan wukuf adalah 9 Dzulhijjah, dimulai dari waktu dzuhur sampai waktu magrib. Firman Allah SWT:

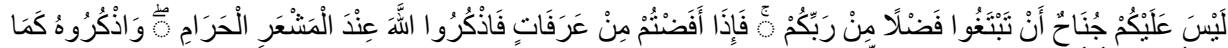

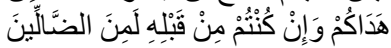

Artinya: "Tidak ada dosa bagimu untuk mencari karunia (rezeki hasil perniagaan) dari Tuhanmu. Maka apabila kamu telah bertolak dari 'Arafat, berdzikirlah kepada Allah di Masy'arilharam. Dan berdzikirlah (dengan menyebut) Allah sebagaimana yang ditunjukkan-Nya kepadamu; dan sesungguhnya kamu sebelum itu benar-benar termasuk orang-orang yang sesat". (QS (2): 198)

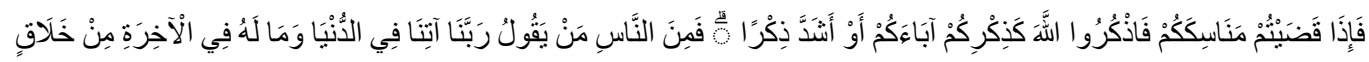

Artinya: "Apabila kamu telah menyelesaikan ibadah hajimu, maka berdzikirlah dengan menyebut Allah, sebagaimana kamu menyebut-nyebut (membanggabanggakan) nenek moyangmu, atau (bahkan) berdzikirlah lebih banyak dari itu. Maka di antara manusia ada orang yang bendoa: "Ya Tuhan kami, berilah kami (kebaikan) di dunia", dan tiadalah baginya bahagian (yang menyenangkan) di akhirat.” (QS (2): 200)

Terdapat dua dimensi dari wukuf ini. Pertama, mengevaluasi kualitas kehidupan kita sebelumnya. Kedua, berkomitmen untuk memperbaiki diri di masa depan atas berbagai kesalahan sebelumnya. Jika seseorang merasa dirinya banyak dosa dan kesalahan, maka disaat inilah orang tersebut menyampaikan pengakuan dosa kepada Allah SWT dan memperbaikinya dimasa depan. Tipikal orang-orang seperti inilah berhaji dengan berbekal ketakwaan. Dengan demikian, wukuf di Padang Arafah adalah suatu proses untuk mengenali diri sejati. Firman Allah SWT (QS (2) 197):

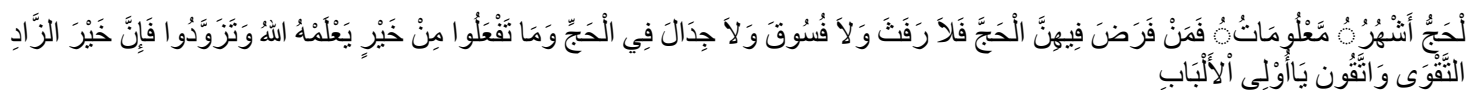

Artinya: "(Musim) haji adalah beberapa bulan yang dimaklumi, barang-siapa yang menetapkan niatnya dalam bulan itu akan menger-jakan haji, maka tidak boleh rafats, berbuat fasik dan berbantah-bantahan di dalam masa mengerjakan haji. Dan apa yang kamu kerjakan berupa kebaikan, niscaya 
Allah mengetahuinya. Ber-bekallah, dan sesungguhnya sebaik-baik bekal adalah takwa dan bertakwalah kepadaKu hai orang-orang yang berakal."

Saat melakukan wukuf di Arafah berbagai kejadian-kejadian yang menandakan tidak adanya perbedaan antara laki-laki dan perempuan, antara kaya dan tak berpunya, antara penguasa dan rakyat jelata, antara umat dan ulama akan terlihat begitu nyata. Saat akan melakukan aktivitas sehari-hari seperti berwudhu, mandi, buang air kecil maupun besar, makan dan sebagainya akan dihadapkan pada antrian yang begitu panjang yang tidak akan terjadi saat berada di hotel dan dikampung halaman kita. Yang tersedia hanyalah berupa tenda dan fasilitas seadanya. Disinilah kita akan diajarkan untuk lebih banyak bersabar dan tabah.

Melontar Jumrah di Mina. Melontar/melempar jumrah merupakan simbolisasi perlawanan seseorang terhadap setan atau ekspresi penolakan terhadap godaan atau rayuan setan yang penuh ingkar. Hal ini dilakukan dengan cara melontar 7 buah batu kerikil ke jumrah (tugu). Melempar jumrah ini awalnya dilakukan oleh nabi Ibrahim kepada setan yang berupaya membujuknya agar membatalkan ujian Allah dalam mengorbankan Nabi Ismail anaknya. Secara emosional, hal ini sangat berat bagi Nabi Ibrahim karena harus membunuh anaknya yang sangat dicintainya. Namun akal Nabi Ibrahim lebih kuat menuntunnya ke arah perintah Allah untuk menaatiNya. Sejarah Nabi Ibrahim ini diceritakan dalam sabda Rasulullah SAW:

" Ketika Nabi Ibrahim akan melaksanakan kurba, setan menampakkkan dirinya di Jumratul Aqabah, lalu beliau melontarnya dengan tujuh buah batu kerikil hingga terbenam didalam tanah. Kemudian setan menampakkan dirinya kedua kali di jamrah, lalu Nabi Ibrahim melontarnya dengan tujuh buah batu kerikil hingga setan terbenam kedalam tanah. Kemudian setan menampakkan ketiga kalinya di Jamrah, lalu beliau melontarnya ke tanah hingga amblas ke dalam tanah. (HR. Baihaqi)".

Prosesi melontar jumrah ini dapat dimaknai bahwa setan dengan berbagai upaya akan selalu menggoda hati dan pandangan manusia, serta berupaya memalingkan dari perintah Allah SWT. Untuk itu, batu yang dilempar merupakan simbol untuk menghalangi tipu daya setan dalam menegakkan kembali perintah Allah SWT. Manusia memiliki fitrah ingin mengabdikan dirinya kepada sang Khalik, namun janji iblis kepada Allah bahwa ia akan selalu menggoda anak Adam hingga terjerumus kedalam lembah kesesatan. Dengan demikian, melontar jumrah dimaknai sebagai penentangan terhadap godaan dan rayuan setan serta mengembalikannya kepada fitrah Rabbnya.

Allah SWT memasukkan sifat-sifat malakiyah(malaikat) dan setaniyah (setan) bagi keturunan Adam. Sehingga manusia memiliki sifat-sifat dualisme, disatu sisi manusia memiliki sifat-sifat ketaatan, akal sehat dan ketaatan; namu disisi lain juga memiki sifat-sifat emosional, keingkaran, dan kesombongan. Jadi, melempar jumrah adalah simbolisasi dalam menundukkan keingkaran sifat-sifat setaniyah itu. Jamaah haji yang tidak berhasil menundukkan atau mengusir sifat-sifat setaniyah maka termasuk dalam kelompok orang-orang yang tidak mabrur hajinya.

Seperti halnya yang terjadi saat wukuf di Arafah, saat berada di Mina untuk melontar kita pun akan dihadapkan pada antrian yang begitu panjang saat melakukan aktivitas sehari-hari seperti berwudhu, mandi, buang air kecil maupun besar, makan dan sebagainya. Maka sifat kesabaran dan ketabahan yang besar akan sangat membantu kita. Seseorang diajarkan untuk lebih bisa mengontrol emosinya dan menanggalkan segala kekuasaan dan kekayaannya saat berada di kampung halamannya.

Thawaf disekeliling ka'bah. Ka'bah merupakan rumah atau tempat peribadatan pertama di dunia yang dibangun manusia sebagai berkah dan petunjuk bagi umat manusia. Nabi Adam as yang melakukan penancapan fondasi ka'bah kenudian terjadi banjir bandang pada masa Nabi Nuh as sehingga merusak bangunan ka'bah kuno. Setelah itu, pembangunan ka'bah berlanjut pada masa Nabi Ibrahim as dan Nabi Ismail as. Keduanya bekerja sama dalam membangun ka'bah, Nabi ismail (saat kecil) bertugas mengusung bebatuan dan Nabi Ibrahim yang menata bangunannya. Hal ini diceritakan Allah SWT dalam firmanNya: 
Artinya: "Sesungguhnya rumah yang mula-mula dibangun untuk (tempat beribadah) manusia, ialah Baitullah yang di Bakkah (Mekah) yang diberkahi dan menjadi petunjuk bagi semua manusia" (QS(3):96).

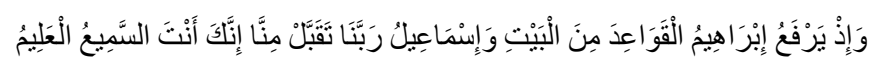

Artinya: "Dan (ingatlah), ketika Ibrahim meninggikan (membina) dasar-dasar Baitullah bersama Ismail (seraya berdoa): "Ya Tuhan kami terimalah daripada kami (amalan kami), sesungguhnya Engkaulah Yang Maha Mendengar lagi Maha Mengetahui".(QS (2): 127)

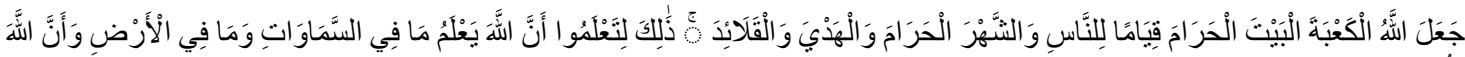

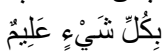

Artinya : "Allah telah menjadikan Ka'bah, rumah suci itu sebagai pusat (peribadatan dan urusan dunia) bagi manusia, dan (demikian pula) bulan Haram, had-ya, qalaid. (Allah menjadikan yang) demikian itu agar kamu tahu, bahwa sesungguhnya Allah mengetahui apa yang ada di langit dan apa yang ada di bumi dan bahwa sesungguhnya Allah Maha Mengetahui segala sesuatu"(QS (5):97).

Saat berthawaf di seputar Ka'bah banyak pelajaran yang dapat kita peroleh yang terkait dengan hablumminallah dan hablumminannas. Yaitu kita diperintahkan untuk berputar mengelilingi Ka'bah sebanyak 7 kali dengan gerakan berputar melawan arah jarum jam namun dalam waktu bersamaan kita bergerak diantara banyak jamaah yang memiliki kehendaknya sendiri. Jumlah putaran tersebut sama dengan jumlah lapisan langit. Hal ini merupakan simbolisasi sekaligus proses belajar merasakan pusaran universal di alam semesta dengan berpusatkan baitullah secara fisik serta meleburkan diri dalam pusaran Baitul Ma'mur bersama para malaikat yang berkeliling di sekitar Arsy Allah SWT. Inilah simbol meleburnya seluruh realitas seorang hamba Allah ke dalam pusaran kehidupan yang berorientasi ketuhanan. Firman Allah SWT (QS (39):75):

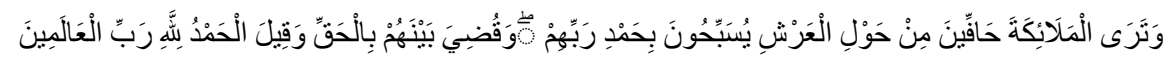

Artinya: "Dan kamu (Muhammad) akan melihat malaikat-malaikat berlingkar di sekeliling `Arsy bertasbih sambil memuji Tuhannya; dan diberi putusan di antara hamba-hamba Allah dengan adil dan diucapkan: "Segala puji bagi Allah, Tuhan semesta alam"."

Sa’i (Berlari kecil antara bukit Shafa dan Marwah). Prosesi ini menjadi simbol bekerja keras tanpa henti yang menjadi penyempurna aktifitas sebelumnya. Prosesi ini mengingatkan kisah Nabi Ismail dan ibunya di padang pasir yang tandus, gersang dan sunyi yang sedang kehausan sepeninggal Nabi Ibrahim. Namun keduanya tabah dalam menghadapinya. Saat ismail kecil menangis karena kelaparan dan kehausan, Sitti hajar, ibu ismail berlari dari bukit Shafa ke bukit Marwah bolak balik hingga hitungan ke 7 . Inilah merupakan cermin keteguhan dalam menjalani hidup pantang berputus asa. Pada akhirnya, Allah SWT memberikan solusi dengan air zam-zam yang keluar dari tanah tempat ia berpijak.

Dengan mengucapkan Bismillahi Allahu Akbar, seseorang mulai ber sa’i untuk kehidupannya. Kadang dilakukan dengan berjalan dan kadang pula dilakukan dengan berlari-lari sepanjang peristiwa yang dilaluinya. Hal yang demikian inilah merupakan cermin keteguhan dalam menjalani hidup yang pantang putus asa. Untuk itu, setelah melaksankan sa'i, jamaah haji disunnahkan meminum air zam-zam sebagai simbol kesuksesan yang telah dilaksanakannya.

Prosesi sa'i ini memberikan pelajaran kepada jamaah haji bahwa seorang muslim hendaknya jangan berputus asa. Bersama dengan kesulitan akan ada kemudahan dan jalan keluar. Terlebih jika seseorang bertawakkal hanya kepada 
Allah SWT. Dalam kondisi apapun seseorang jangan sampai melupakan untuk bertawakkal kepada Allah SWT. Seperti pada firman Allah surah:

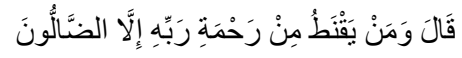

Artinya: "Ibrahim berkata: "Tidak ada orang yang berputus asa dari rahmat Tuhannya, kecuali orang-orang yang sesat". (QS (15): 56)

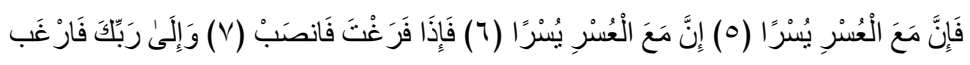

Artinya: "Karena sesungguhnya sesudah kesulitan itu ada kemudahan. Sesungguhnya sesudah kesulitan itu ada kemudahan. Maka apabila kamu telah selesai (dari sesuatu urusan), kerjakanlah dengan sungguh-sungguh (urusan) yang lain. Dan hanya kepada Tuhanmulah hendaknya kamu berharap" (QS (94):5-8).

Dari penjelasan tentang prosesi pelaksanaan haji diatas, dapat disimpulkan beberapa perbedaan fokus kekhusyukan antara wukuf di Arafah, lempar jumrah di Mina, Thawaf dan sa'i di Mekkah. Saat wukuf di Arafah seseorang diarahkan untuk lebih tertuju pada evaluasi segala perbuatan sebelumnya (introspeksi diri). Lempar jumrah di Mina perhatian seseorang ditujukan pada tekat untuk mengusir sifat-sifat setaniyah yang ada dalam diri seseorang. Saat melakukan Thawaf, perhatian seseorang diarahkan agar terpusat pada 'merasakan interaksi' dengan Allah SWT, alam semesta, dan manusia yang berada di sekeliling kita yang sedang bergerak melebur dalam kesatuan tunggal gerakan thawaf. Sedangkan pada kegiatan Sa'i lebih ditujukan kepada komitmen untuk bekerja keras, dan pantang berputus asa. Dalam konteks akuntansi, prosesi-prosesi ibadah haji yang mengandung nilai pengorbanan, keikhlasan, ketabahan, introspeksi diri, komitmen bekerja keras, pantang berputus asa sebaiknya juga dijadikan sandaran dalam membangun akuntansi syariah.

\begin{abstract}
Akuntabilitas Setelah Memenuhi PanggilanNya Berhaji (Nilai Penyerahan Diri dan Pengendalian Diri bagi Akuntansi Syariah). Haji merupakan gambaran puncak keislaman seseorang, bukan untuk dijadikan sebagai ajang dalam mencari kehormatan dalam masyarakat ataupun kelompok eksklusif. Karena sesungguhnya dalam melaksanakan ibadah haji seseorang diajarkan untuk inklusif dan universal. Dikatakan universal karena saat berada disana, tidak ada perbedaan yang membedakan antara satu individu dengan individu lainnya, antara laki-laki dan perempuan, antara kaya dan tak berpunya, antara penguasa dan rakyat jelata, antara umat dan ulama, bahkan terdapat kesetaraan antara semua bangsa dan golongan.

Haji dari seorang individu adalah dimana individu yang telah berhaji membawa dampak perubahan spiritual dan sosial di lingkungan masyarakat. Seorang haji mabrur akan terlihat dari peningkatan kualitas akhlak dan moralitasnya tidak hanya pada saat berhaji namun juga ketika pulang setelah berhaji. Seperti dijelaskan diatas bahwa haji merupakan puncak kualitas keislaman sesorang, secara spiritual, yang bisa mengantarkannya pada sifat untuk senantiasa berserah diri sepenuhnya kepada Sang Khalik, seseorang yang belum berserah diri belum patut dikatakan haji meskipun telah berulang kali ketanah suci. Bahkan orang yang tinggal di tanah suci pun belum tentu memperoleh kualitas haji yang lebih baik bila dibandingkan dengan orang yang tidak tinggal ditanah suci namun setelah kembali dari sana tetap selalu mendekatkan diri kepada Allah SWT. Firman Allah SWT (QS (6):163):
\end{abstract}

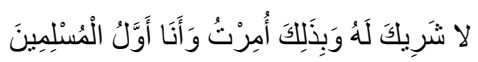

Artinya: "Tiada sekutu bagi-Nya; dan demikian itulah yang diperintahkan kepadaku dan aku adalah orang yang pertama-tama menyerahkan diri (kepada Allah)".

Pelajaran sifat berserah diri merupakan hasil dari peleburan dari sifat ketaatan, kesabaran, pengorbanan dan keikhlasan yang telah dipelajari saat melaksanakan prosesi-prosesi haji. Untuk itu, setelah melaksanakan ibadah haji 
sesorang harusnya lebih taat, sabar dalam bertindak, pantang putus asa, ikhlas dalam beramal, dan memiliki perasaan berkorban serta senantiasa mengendalikan diri dari koridor-koridor yang tidak seharusnya karena hal-hal tersebut merupakan akuntabilitas kita kepada Sang Khalik. Setelah pulang dari berhaji, seorang haji yang sukses adalah seorang haji yang berubah secara akhlak. Menjadi lebih taat dalam beragama, menjadi lebih penyantun, sabar dan lembut hati kepada siapa saja. Selain itu lebih ikhlas, tawadhu dalam berbuat, lebih suka berkorban dan beramal kebajikan lebih banyak demi kemaslahatan umat. Haji seperti itulah yang dikenal sebagai haji mabrur.

Tanda-tanda haji yang mabrur menurut para ulama yaitu, diantaranya Imam Hasan Al Bashri rahimahullah berkata: "Haji yang mabrur adalah agar ia pulang dari ibadah haji menjadi orang yang zuhud dalam kehidupan dunia dan cinta akhirat". Orang yang zuhud adalah bukan berarti orang yang hanya beribadah di Mesjid lalu tidak mau bekerja mencari harta sebagai nafkah anak dan isteri namun orang yang zuhud yaitu orang yang tidak diperbudak oleh hartanya, namun harta yang dimilikinya sebagai jembatan untuk lebih dekat kepada Sang Khalik tidak memutuskan silaturahmi, tetap rajin menuntut ilmu islam lalu mengamalkan dan mendaâwahkannya. Tidak melupakan tanggung jawab mendidik isteri dan anakanak. Orang yang zuhud adalah orang yang penghasilannya halal, bukan dari hasil renten, riba, suap, korupsi, mencuri, judi, pungli, memeras, menipu, memakan hak orang lain. Firman Allah SWT (QS (28):77):

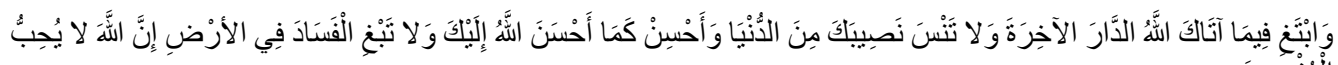

Artinya: "Dan carilah pada apa yang telah dianugerahkan Allah kepadamu (kebahagiaan) negeri akhirat, dan janganlah kamu melupakan bahagianmu dari (kenikmatan) duniawi dan berbuat baiklah (kepada orang lain) sebagaimana Allah telah berbuat baik, kepadamu, dan janganlah kamu berbuat kerusakan di (muka) bumi. Sesungguhnya Allah tidak menyukai orang-orang yang berbuat kerusakan."

Seperti yang penulis katakan sebelumnya bahwa diantara tanda haji yang mabrur yaitu setelah pulang melaksanakan ibadah haji, seseorang menjadi lebih baik dari sebelumnya. Menjadi lebih baik dalam hal tauhid. Misalnya, jika ada diantara jamaah haji yang sebelum hajinya masih suka pergi ke dukun untuk minta kekayaan, anak, jodoh, cepat naik pangkat dan lain-lain maka setelah berhaji haruslah bertaubat kepada Allah dan hendaklah orang tersebut meninggalkannya. Sebab Rasulullah SAW bersabda yang artinya, "Barangsiapa mendatangi tukang ramal atau dukun lalu membenarkan apa yang dikatakannya, maka ia telah kafir dengan apa yang telah diturunkan kepada Muhammad". (HR. Abu Dawud, AtTirmidzi, Ibnu Majah, dishahihkan oleh Al-Albani dalam Al-Irwa' no. 2006).

Selain itu, barangsiapa yang sebelum haji, suka menyembelih sapi atau lainnya untuk dijadikan sebagai tumbal atau sesajen maka sudah seharusnya meninggalkannya dan menyembelih kurban hanya untuk Allah SWT karena Allah berfirman yang artinya: "Maka dirikanlah shalat karena Rabbmu dan berkorbanlah" (QS (108):2) "Katakanlah sesungguhnya shalatku, sesembelihanku, hidup dan matiku hanya untukAllah Rabbul Alamin tidak ada sekutu baginya" (QS (6): 162).

Sementara, barangsiapa yang sebelum haji, masih memiliki kepercayaan dalam ramalan bintang maka tinggalkanlah dan bertawakallah kepada Allah semata. Barangsiapa yang sebelum berhaji masih sering mengkeramatkan keris dan jimatjimat, maka sekarang musnahkanlah segala jimat yang dimiliki tersebut. Barangsiapa yang sebelum berhaji masih suka meruwat bumi untuk menghindarkan bencana, maka setelah berhaji sebaiknya bertaubat dan tinggalkan upacara syirik tersebut, sebaiknya bergantung kepada Allah karena yang dapat menghindarkan segala bencana hanya Allah SWT semata.

Selain itu, Barangsiapa yang sebelum berhaji masih mengkeramatkan sapi yang dikeluarkan setiap tanggal sepuluh Muharram bahkan berebut untuk memperoleh kotorannya yang biasanya dianggap dapat memberikan berkah, maka 
ketahuilah itu merupakan salah satu perbuatan syirik. Barangsiapa yang sebelum berhaji masih meyakini bahwa nasib sial akan menimpa seseorang jika bepergian hari Selasa atau Sabtu juga untuk menentukan waktu pernikahan harus dihitung secara cermat karena kalau tidak pas harinya akan menimbulkan kesialan, maka itu semua juga merupakan syirik. Allah tidak mengampuni dosa syirik kecuali jika pelakunya bertaubat, sesungguhnya Allah SWT Maha Penerima taubat. Allah mengharamkan surga bagi orang yang berbuat syirik. Adapun orang-orang yang beriman dan tidak mencampur adukkan keimanan mereka dengan kesyirikan maka mereka mendapatkan keamanan dan hidayah dari Allah SWT.

Hendaklah jamaah haji memperbaiki ibadahnya kepada Allah SWT, shalat yang lima waktu jangan pernah ditinggalkan, zakat maal harus dikeluarkan dan puasa di bulan Ramadhan harus selalu dijalankan. Segala ibadah dilaksanakan dengan penuh rasa cinta kepada Allah SWT yang telah memberikan nikmat yang tidak terhingga. Seseorang siap berkorban baik harta, tenaga dan waktu demi menggapai ridha Allah SWT. Hendaklah seseorang memperbaiki muamalahnya dengan orang tua yang telah melahirkan dan mendidiknya sejak kecil. Jangan sampai menyakiti hati mereka dan hendaklah selalu berbakti dan memperlakukan mereka dengan sebaik-baiknya perbuatan. Jika orang tua telah meninggal dunia hendaklah selalu mendoakan mereka.

Bagi para suami hendaklah memperbaiki muamalah dengan isterinya, jangan mudah marah (mengikuti sifat-sifat setaniyahnya) dan membentak isterinya jika berbuat kesalahan. Lakukanlah hal-hal yang menyenangkan isteri selama tidak bertentangan dengan syariat islam. Didiklah isteri dengan nasehat, membawanya ke majelis taâlim, membelikannya buku dan kaset ceramah yang bermanfaat. Juga didiklah isteri dengan memberi keteladanan Rasulullah SAW bersabda: "Sebaik-baik kalian adalah yang terbaik terhadap keluarganya dan saya adalah orang yang paling baik diantara kalian terhadap keluargaku".

Bagi para isteri perbaikilah muamalah dengan suami jadilah isteri yang taat. Rasulullah SAW bersabda: "Apabila wanita shalat yang lima waktu, berpuasa di bulan Ramadhan, taat kepada suaminya dan memelihara kemaluannya, maka ia masuk surga dari pintu-pintu mana saja yang ia mau". Ketaatan kepada suami dalam hal yang makruf saja adapun dalam hal maksiat tidak ada ketaatan kepada makhluk dalam hal maksiat kepada Allah Al-Khaliq. Ketika suami baru datang dari pekerjaan janganlah disambut dengan berbagai macam problem dan hal-hal yang tidak menyenangkan tetapi sambutlah dengan senyum, sediakanlah makan dan minum serta biarkanlah suami untuk istirahat dulu setelah itu barulah sampaikan segala problem yang ada niscaya suami sudah lebih siap untuk mendengarkannya.

Bagi para orang tua perbaikilah dalam pendidikan terhadap anak-anak, mereka merupakan amanat yang kelak kita akan diminta pertanggungjawabannya /akuntabilitas di hari akhir. Didiklah mereka dengan memberikan contoh yang baik, sekolahkanlah mereka di tempat yang baik, awasilah pergaulan mereka. Selalulah berdoa kepada Allah agar melindungi dan menjaga mereka dari segala kejahatan dan keburukan karena doa dari orang tua untuk anaknya insya Allah mustajab. Bagi kaum muslimah perbaikilah dalam hal berbusana, tutuplah aurat anda dan jangan diperlihatkan kepada laki-laki yang bukan muhrimnya. Allah berfirman dalam surah Al-Ahzab ayat 59:

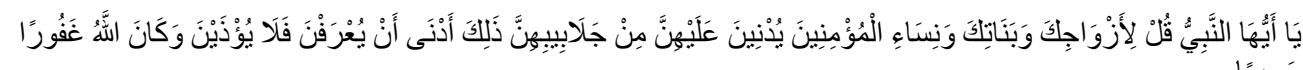

Artinya: "Hai Nabi katakanlah kepada isteri-isterimu, anak-anak perempuanmu, dan isteri-isteri orang mukmin, (Hendaklah mereka mengulurkan jilbabnya ke seluruh tubuh mereka). Yang demikian itu supaya mereka lebih mudah untuk dikenal, karena itu mereka tidak diganggu. Dan Allah adalah Maha Pengampun lagi Maha Penyayang”. (QS (33): 59) 


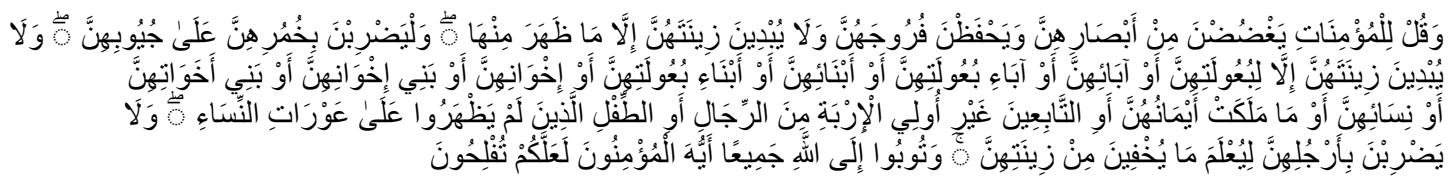

Artinya:"Katakanlah kepada wanita yang beriman, hendaklah mereka menahan pandangannya, dan memelihara kemaluannya, dan janganlah mereka menampakkan perhiasannya, kecuali yang (biasa) nampak dari padanya. Dan hendaklah mereka menutupkan kain kudung ke dadanya, dan janganlah menampakkan perhiasannya, kecuali kepada suami mereka, atau ayah mereka, atau ayah suami mereka, atau putera-putera mereka, atau putera-putera suami mereka, atau saudara-saudara laki-laki mereka, atau putera-putera saudara laki-laki mereka, atau putera-putera saudara perempuan mereka, atau wanita-wanita Islam atau budak-budak yang mereka miliki, atau pelayan-pelayan laki-laki yang tidak mempunyai keinginan (terhadap wanita) atau anak-anak yang belum mengerti tentang aurat wanita. Dan janganlah mereka memukulkan kakinya agar diketahui perhiasan yang mereka sembunyikan. Dan bertaubatlah kamu sekalian kepada Allah, hai orang-orang yang beriman supaya kamu beruntung". (QS (24): 31)

Rasulullah SAW bersabda: "Ada dua golongan dari penduduk neraka yang belum pernah saya lihat keduanya (sebelum ini), (pertama) suatu kaum yang memiliki cambuk bagaikan ekor sapi yang digunakannya untuk memukul manusia dan (kedua) wanita yang berpakaian tapi telanjang berjalan berlenggak lenggok, kepala mereka seperti punuk unta, mereka tidak masuk surga dan tidak mencium bau surga padahal bau surga itu tercium dari jarak yang sekian dan sekian jauhnya". (Hadits Shahih, Riwayat Muslim)

Saat ini, masih banyak diantara jamaah haji wanita yang berpakaian tapi seperti telanjang (misalnya dengan baju berbahan brokat transparan), belum sempurna menutup auratnya, ada yang masih terlihat lehernya, terlihat lengannya, menutup aurat dengan pakaian yang ketat sehingga membentuk lekak lekuk tubuhnya, berpakaian dengan bahan yang tipis dan transparan sehingga terlihat kulitnya dan lain sebagainya. Hendaklah jamaah haji wanita menjadi sadar setelah menangis dan memohon ampun kepada Allah pada saat wuquf di Arafah. Hendaklah jamaah haji wanita menjadi teladan bagi kaum muslimah di tanah air yang sedang dilanda dekadensi akhlak dan moral. Didiklah puteri-puteri kita agar berbusana muslimah, nasehatilah mereka agar tidak keluar rumah dengan menggunakan celana pendek, celana panjang lebih-lebih celana yang sangat ketat dan perutnya terlihat,Astagfirullahul aziim...

Hendaklah kita semua memperbaiki diri dalam hal tanggung jawab untuk memperbaiki masyarakat. Bentengi aqidah umat dengan cara menyebarkan ilmu yang bermanfaat, dengan saling nasehat menasehati untuk menepati kebenaran dan nasehat menasehati untuk menetapi kesabaran, dengan saling bekerjasama dalam hal kebaikan dan taqwa. Tidak sedikit umat Islam di Indonesia murtad dari agamanya disebabkan kelengahan dan kelalaian kita. Benar sebab mereka murtad adalah karena lemah iman ditambah lagi dengan lemah ekonomi, tapi apakah boleh kita diam dan berpangku tangan? Tidak, kita harus berbuat sesuai dengan kemampuan kita. Apabila kita tidak bisa mendidik mereka karena keterbatasan ilmu kita, ajaklah mereka untuk menghadiri majelis-majelis ilmu, pinjamkan kaset-kaset ceramah yang bermanfaat, bagikan buletin dan buku-buku Islam.

Bagi jamaah haji yang telah kembali ketanah air, perasaan rindu untuk kembali lagi berkunjung ke Baitullah terkadang terasa lebih kuat jika dibandingkan dengan yang belum pernah berkunjung. Hal ini akan dirasakan oleh individu yang betul-betul menjiwai dan menikmati pemaknaan dari ritual-ritual yang dilakukan dalam berhaji. Perasaan tersebut, akan menimbulkan keinginan untuk kembali lagi berhaji. Namun keinginan seperti itu sebaiknya dikendalikan, mengingat banyaknya umat islam di Indonesia yang telah lama menunggu antriannya untuk melakukan ibadah haji. Imam Besar Masjid Istiqlal, KH Ali Musthafa Ya'qub dalam forum 
legislasi bertema RUU Penyelenggara Haji dan Umroh" di gedung DPR, Jakarta, Selasa $(11 / 8 / 2015)$ menegaskan bahwa "naik haji berulang kali justru menzalimi orang lain, terutama dari kalangan duafa yang naik haji untuk pertama kali"

Dalam forum yang sama, pembicara lain yaitu Dading Ishak (Wakil Ketua Komisi VIII DPR) dan Wakil Ketua Umum Ikatan Persaudaraan Haji Indonesia (IPHI) Anshori mengatakan "Berhaji berulang kali sebagai penzaliman,". Menurut dia, beberapa buku yang ditulis ulama besar yang menyebutkan kalau naik haji berulang kali sebagai bentuk penzaliman. Di Arab, orang naik haji cukup satu kali. Namun hal itu berbeda dengan kebiasaan orang Indonesia, terutama yang berkantung tebal. Menurut Halim di suatu daerah misalnya, banyak kalangan masyarakatnya yang setiap tahun naik haji. Alhasil, menurut dia, orang yang naik haji berulang kali hanya sekadar pamer dan menjadi sombong. Menunaikan ibadah haji sesungguhnya diwajibkan satu kali. "Kenapa disebut penzaliman? Dengan berulang kali naik haji, mengambil jatah orang yang pertama kali naik haji. Mereka terpaksa mengantri," ujarnya. Rasullah pun ujarnya sebenarnya bisa melaksanakan haji sampai tiga kali. Namun tidak dilakukan dan hanya satu kali saja melaksanakan rukun Islam kelima tersebut.

Para ulama dari seluruh mazhab juga bersepakat, bahwa hukum asal haji berulang kali adalah mandub (sunnah). Kewajiban haji hanya sekali saja seumur hidup. Inilah yang diistilahkan dengan haji wajib. KH Ma'ruf Amin sebagai Ketua Tim Materi dalam ijtima' ulama juga menegaskan, orang yang telah melaksanakan ibadah haji satu kali (haji wajib) berarti sudah terpenuhi kewajibannya. Hal ini mengacu pada hadis dari Ibnu Abbas RA. Ketika Rasulullah SAW ditanya salah seorang sahabat al-Aqra' bin Abis tentang haji berulang kali, Beliau SAW bersabda, "(haji) hanya satu kali saja. Siapa yang menambah, maka itu sunat (tatawwu')." (HR Abu Daud).

Disamping itu para ulama juga bersepakat, hukum asal melarang orang lain yang ingin menunaikan haji ke Tanah Suci adalah haram. Hal ini secara tegas disebut dalam Alquran, "Dan siapakah yang lebih zalim daripada orang yang melarang di dalam masjid-masjid Allah untuk menyebut nama-Nya." (QS (2):114). Jadi, jika ada individu yang ingin melaksanakan ibadah haji ke Tanah Suci, walaupun dirinya sudah melaksanakan haji berulang kali, adalah haram hukum asalnya. Namun, jika seseorang yang sudah berulangkali haji ini tetap mendaftar berangkat haji lagi tanpa mempedulikan orang lain yang belum berangkat haji, justru dirinya bisa menghalangi orang lain berangkat haji ke Tanah Suci. Jadi, orang yang sudah haji, harus memberikan kesempatan kepada orang lain untuk melaksanakan haji wajibnya, karena keterbatasan kuota dan antrian keberangkatan yang lama.

Memberikan prioritas kepada orang yang ingin melaksanakan haji wajib ketimbang mereka yang hanya berangkat haji berulang (sunat) juga berdalil dengan kaidah fikih, "Ma la yatimmu al-wajibu illa bihi, fahuwal wajib" (Sesuatu yang jika tanpanya hal wajib tidak bisa ditunaikan, maka sesuatu itu juga menjadi wajib). Misalnya, shalat adalah wajib dan shalat tidak bisa ditunaikan tanpa adanya wudhu'. Maka wudhu' bagi orang yang akan shalat pun ikut terbawa jadi wajib. Demikian juga, orang yang ingin menunaikan haji wajib berada dalam antrian panjang keberangkatan haji. Ia menjadi wajib diprioritaskan untuk berangkat haji ketimbang orang yang berangkat haji sunat. Alasannya, haji wajib juga mewajibkan hal-hal yang menjadi mediator terlaksananya kewajiban hajinya. Ibnu Hajar dalam kitab Fathul Barrinya juga menegaskan, "melakukan yang wajib harus didahulukan daripada melakukan amalan tathawwu' (sunat)." Jika bertemu antara yang wajib dan yang sunat, maka yang wajib akan menjadi prioritas untuk di dahulukan. Demikian juga soal keberangkatan haji. Dalam putusan komisi Fatwa yang menangani soal Fiqhiyah Mu'ashirah ini memberikan rekomendasi kepada pemerintah. Mengingat panjangnya antrean berangkat haji, mereka yang hendak melaksanakan haji sunat hendaknya dipisahkan antreannya dari mereka yang hendak berangkat haji wajib.

Disamping itu, komisi fatwa tersebut juga merekomendasikan agar orang yang berangkat haji berulang perlu dibatasi. Kecuali bagi mereka yang memang memiliki hajat tertentu, seperti petugas, pembimbing, dan pendamping calon haji yang dibutuhkan. Para ulama juga menganjurkan, sebaiknya Biaya Perjalanan Ibadah Haji 
(BPIH) orang yang haji berulang lebih afdhal (utama) untuk disedekahkan. Hal ini lebih bermanfaat untuk mewujudkan izzul Islam wal muslimin (ibadah yang berdimensi sosial) seperti peduli anak yatim, dhuafa, dan tetangga yang berkekurangan. Bisa juga diberikan guna pembangunan masjid, lembaga pendidikan, panti asuhan, beasiswa pendidikan, dan sejenisnya. Dalam kaitannya dengan ilmu akuntansi maka, nilai penyerahan diri dan pengendalian diri dapat dijadikan sebagai nilai dasar dalam penyempurnaan akuntansi syariah sehingga saat akuntansi syariah yang terbentuk telah pada tahap yang seharusnya tidak lagi mudah untuk terkontaminasi oleh hal-hal yang berbaur kapitalime seperti pada akuntansi konvensional saat ini.

\section{SIMPULAN}

Akuntansi syariah menurut Triyuwono (2009) merupakan seni dan ilmu meracik informasi akuntansi yang berfungsi sebagai doa dan dzikir untuk memenuhi kebutuhan ekonomi, mental dan spiritual manusia dalam rangka beribadah dan kembali pada Tuhan dengan jiwa yang suci dan tenang. Akuntansi Syariah yang banyak tumbuh saat ini, telah memberikan nilai pencerahan pada ilmu akuntansi, hal ini disebabkan karena syariahnya menempatkan setiap pekerjaan dalam sebuah organisasi maupun individu dengan nilai "ibadah" (Adlan:2009). Ibadah yang dilakukan individu dalam interaksi sosial masyarakat akan berubah pada ibadah sosial, dan ibadah sosial akan membentuk individu-individu yang beribadah sehingga tujuan dasar dari akuntansi sebagai alat penyampai informasi benar-benar memiliki nilai akuntabilitas yang tinggi. Akuntabilitas yang tinggi inilah merupakan dasar dari akuntansi syariah yang sesungguhnya.

Salah satu bentuk dari akuntabilitas individu dan sosial bangsa indonesia kepada Allah SWT adalah dengan melaksanakan ibadah haji yang merupakan rukun Islam yang kelima. Perintah melaksanakan ibadah haji ini telah diamanahkan pada seluruh umat islam didunia sebagaimana yang tercantum pada Al-qur'an dan Al Hadits yang merupakan pedoman hidup umat islam diseluruh dunia. Secara spiritual, ibadah ini memilki daya pikat yang luar biasa. Berbagai ritual-ritual yang ada dalam pelaksanaan haji terkandung nilai-nilai yang dapat dijadikan sandaran dalam membangun akuntansi syariah, karena ibadah haji itu sendiri merupakan akuntabilitas umat islam kepada sang khalik. Nilai-nilai tersebut seperti pengorbanan, introspeksi diri, komitmen bekerja keras, dan pantang berputus asa.

Manfaat ibadah Haji adalah sebagai pembersihan jiwa dan Hubungan Allah dan Rasul-Nya. Jadi, Ibadah adalah realisasi keimanan kepada Allah, dan tanda penyerahan diri kepada-Nya. Orang yang menjadikan ibadah sebagai jiwa aktifitas pengisi waktunya, ia akan tetap tenang hatinya, tentram jiwanya dalam menghadapi situasi dan kondisi kehidupannya karena ia menyerahkan diri sepenuhnya kepada Allah SWT, dengan melaksanakan segala perintah-Nya dan menjauhi segala laranganNya, sesuai dengan kemampuannya. Karena hal inilah sehingga penulis katakan bahwa ibadah haji merupakan wujud akuntabilitas individu kepada sang Khalik. Demikian pula halnya akuntansi syariah sebaiknya dibangun dengan pondasi keimanan kepada Allah SWT sehingga aktivitas akuntansi syariah yang dijalankan adalah ibadah sebagai bentuk akuntabilitas para akuntan yang menjadikan tenang hatinya dan tentram jiwanya dalam menghadapi berbagai situasi dan kondisi apapun.

Haji adalah ibadah yang istimewa jika dilihat dari beratnya persyaratan, prosesi ibadah dan reward yang dijanjikan oleh Sang Pemilik Kehidupan, Allah SWT. Karenanya sangat masuk akal jika haji ditempatkan sebagai rukun Islam yang ke lima., setiap umat islam berkewajiban menjalankan ibadah haji bagi yang memiliki kemampuan. Yaitu sehat jasmani dan rohani serta mempunyai perbekalan yang cukup untuk pulang dan pergi. Artinya, jika seseorang telah memiliki kemampuan menunaikan ibadah haji namun tidak mau melaksanakannya dengan berbagai alasan maka orang tersebut dianggap belum menyempurnakan keislamannya. Jadi apabila saat ini kita telah memiliki kemampuan untuk mendaftar haji dan memiliki tubuh yang sehat untuk melaksanakan ibadah haji maka sebaiknya kita menyegerakan untuk berhaji. Implikasi dalam akuntansi yaitu bahwa individu yang terlibat dalam praktik bisnis harus selalu melakukan pertanggungjawaban (akuntabilitasnya) apa 
yang telah diamanahkan dan diperbuat kepada pihak-pihak yang terkait dalam rangka beribadah dan kembali pada Tuhan dengan jiwa yang suci dan tenang. Dalam hal ini, wujud akuntabilitasnya yaitu dalam bentuk laporan akuntansi yang amanah dan suci.

Terkait dengan haji sebagai bentuk akuntabilitas umat islam, maka penulis membaginya dalam tiga kategori yaitu:

1. Akuntabilitas Dalam Upaya Menuju PanggilanNya (Berhaji)/ Nilai motivasi (berikhtiar) bagi akuntansi syariah.

Setiap umat islam, memiliki akuntabilitas untuk memotivasinya dirinya dalam melaksanakan ibadah haji bagi yang telah memiliki kemampuan. Tentunya dalam hal ini adalah motivasi yang berbasis religiusitas. Yaitu spirit yang terkandung dalam individu yang melaksanakan haji, pure atau murni sematamata hanya karena ingin mendekatkan diri kepada Allah SWT, lebih menguatkan iman dan untuk menyempurnakan rukun islam yang kelima (M.Sulthoni, et al., 2012). Demikian pula dalam hal akuntansi, motivasi yang berbasis religiusitas haruslah menjadi sandaran dalam membentuk akuntansi syariah sehingga spirit yang terkandung dalam akuntansi syariah murni semata-mata untuk mencapai ridhoNya.

Kemampuan fisik dan kemampuan materi merupakan upaya (ikhtiar) yang harus dilakukan bagi setiap individu. Ikhtiar adalah usaha seorang individu untuk mencapai tujuan atau keinginannya. Untuk itu, sudah menjadi kewajiban bagi setiap individu untuk melakukan ikhtiar agar memiliki kemampuan fisik dan kemampuan materi. Seberapa besar upaya seseorang tersebut, Sang Khalik akan mengetahuinya. Selain ikhtiar setiap umat islam juga memiliki hak untuk berdoa kepada Sang Khalik agar keinginan dan tujuan berhaji dapat tercapai. Demikian pula halnya dalam konteks aplikasi akuntansi, upaya-upaya (ikhtiar) untuk melakukan dekonstruksi terhadap bangun akuntansi modern menuju pada bangun akuntansi (alternatif) yang lebih baik dalam upaya agar senantiasa kembali kepada fitrah yang seharusnya.

2. Akuntabilitas Saat Memenuhi PanggilanNya (Berhaji)/ Nilai Pengorbanan, Introspeksi Diri, Komitmen Bekerja Keras, Pantang Berputus Asa Bagi Akuntansi Syariah

Saat pelaksanaan ibadah haji, seorang yang berhaji harus mengetahui dan menjalankan rukun haji. Rukun haji merupakan hal-hal atau amalan-amalan yang wajib dikerjakan dalam proses pelaksanaan ibadah haji. Amalan-amalan tersebut, tidaklah bisa ditinggalkan dan tidak dapat digantikan dengan membayar dam (denda). Seorang calon haji yang tidak mengerjakan salah satu dari rukun haji maka hajinya tidaklah sah baik itu disengaja, alpa, atau tidak tahu.

Prosesi Ibadah haji merupakan prosesi pensucian jiwa manusia dan perpaduan kemampuan hati, fisik dan harta. Dalam haji kita diajarkan untuk berkorban dan berserah diri kepada Allah SWT yang seharusnya kita lakukan dan merupakan wujud akuntabilitas kita kepada sang khalik. Menurut Agus Mustofa, Ketika kita bisa menjalankan ibadah haji dalam keadaan berkorban, berada dalam kesempitan, namun bisa melaksanakan adalah suatu hal yang luar biasa. Berbeda halnya jika orang menjalankan ibadah haji ketika dalam kondisi lapang, tentunya rasa pengorbanannya jauh berkurang. Rasa pengorbanan itulah yang memperoleh keridhaan Allah SWT dengan kualitas yang tinggi.

Prosesi-prosesi saat pelaksanaan ibadah haji memiliki makna yang sangat kaya diantaranya yaitu Saat wukuf di Arafah seseorang diarahkan untuk lebih tertuju pada evaluasi segala perbuatan sebelumnya (introspeksi diri). Lempar jumrah di Mina perhatian seseorang ditujukan pada tekat untuk mengusir sifatsifat setaniyah yang ada dalam diri seseorang. Saat melakukan Thawaf, perhatian seseorang diarahkan agar terpusat pada 'merasakan interaksi' dengan Allah SWT, alam semesta, dan manusia yang berada di sekeliling kita yang 
sedang bergerak melebur dalam kesatuan tunggal gerakan thawaf. Sedangkan pada kegiatan Sa'i lebih ditujukan kepada komitmen untuk bekerja keras, dan pantang berputus asa. Berbagai macam makna yang terkandung dalam prosesi inilah yang seharusnya melekat dalam diri seorang haji. Dalam konteks akuntansi, prosesi-prosesi ibadah haji yang mengandung nilai pengorbanan, keikhlasan, ketabahan, introspeksi diri, komitmen bekerja keras, pantang berputus asa sebaiknya juga dijadikan sandaran dalam membangun akuntansi syariah.

3. Akuntabilitas Setelah Memenuhi PanggilanNya (Berhaji)/ Nilai Penyerahan Diri dan Pengendalian Diri bagi Akuntansi Syariah.

Haji dari seorang individu adalah dimana individu yang telah berhaji membawa dampak perubahan spiritual dan sosial di lingkungan masyarakat. Seorang haji mabrur akan terlihat dari peningkatan kualitas akhlak dan moralitasnya tidak hanya pada saat berhaji namun juga ketika pulang setelah berhaji. Seperti dijelaskan diatas bahwa haji merupakan puncak kualitas keislaman sesorang, secara spiritual, yang bisa mengantarkannya pada sifat untuk senantiasa berserah diri sepenuhnya kepada Sang Khalik, seseorang yang belum berserah diri belum patut dikatakan haji meskipun telah berulang kali ketanah suci. Bahkan orang yang tinggal di tanah suci pun belum tentu memperoleh kualitas haji yang lebih baik bila dibandingkan dengan orang yang tidak tinggal ditanah suci namun setelah kembali dari sana tetap selalu mendekatkan diri kepada Allah SWT.

Pelajaran sifat berserah diri merupakan hasil dari peleburan dari sifat ketaatan, kesabaran, pengorbanan dan keikhlasan yang telah dipelajari saat melaksanakan prosesi-prosesi haji. Untuk itu, setelah melaksanakan ibadah haji sesorang harusnya lebih taat, sabar dalam bertindak, pantang putus asa, ikhlas dalam beramal, dan memiliki perasaan berkorban karena hal-hal tersebut merupakan akuntabilitas kita kepada Sang Khalik. Setelah pulang dari berhaji, seorang haji yang sukses adalah seorang haji yang berubah secara akhlak. Menjadi lebih taat dalam beragama, menjadi lebih penyantun, memiliki pengendalian diri yang tinggi, sabar dan lembut hati kepada siapa saja. Selain itu lebih ikhlas, tawadhu dalam berbuat, lebih suka berkorban dan beramal kebajikan lebih banyak demi kemaslahatan umat. Haji seperti itulah yang dikenal sebagai haji mabrur. Dalam kaitannya dengan ilmu akuntansi maka nilai penyerahan diri dan pengendalian diri dapat dijadikan sebagai nilai dasar dalam penyempurnaan akuntansi syariah sehingga saat akuntansi syariah yang terbentuk telah pada tahap yang seharusnya tidak lagi mudah untuk terkontaminasi oleh hal-hal yang berbaur kapitalime seperti pada akuntansi konvensional saat ini.

\section{DAFTAR PUSTAKA}

Al Qur'an \& Terjemahan. (2005). Departemen Agama RI. Penerbit PT. Syaamil Cipta Media, Bandung

Abdurrahman, M. (2009.). Bersujud di Baitullah: Ibadah Haji, Mencari Kesalehan Hidup. Jakarta: Buku Kompas.

Al-Musyaiqih, \& Ali, K. b. (2009). Buku Ibadah Lengkap dan Mudah (A. Qahar, Trans.). Hussain, S. S. (1996). Human Rights in Islam (A. Rahim, Trans.). Jakarta: Gema Insani Press.

M.Sulthoni, Muhlisin, \& Mutho'in. (2012). HAJI DAN KEGAIRAHAN EKONOMI: Menguak Makna Ibadah Haji Bagi Pedagang Muslim di Yogyakarta Jurnal Penelitian, 9(1), 49-65.

Mustofa, A. (2009). Menjadi Haji Tanpa Berhaji. Surabaya: PADMA Press.

M. Masrur Huda, S. S., M. Pd.I. (2012). Syubhat Seputar Haj dan Umrah. Solo: Tinta Medina, Creative Imprint of Tiga Serangkai.

Mas'ud, Ibnu, \& Abidin, Z. (2007). Fiqih Mazhab Syafi'i. Bandung: Pustaka Setia. 
Mulawarman, A. D. (2008b). Penyucian Pendidikan Akuntansi Episode Dua: Hyper View of Learning dan Implementasinya. Tema, 9(1), 53-66.

Putuhena, \& Saleh, M. (2007). Historiografi Haji di Indonesia. Yogyakarta: LKiS.

Qardawi, \& Yusuf. (2002). Fatwa-Fatwa Kontemporer (A. H. a. Kattani, Trans.). Jakarta: Gema Insani Press.

Qardawi, \& Yusuf. (2007). Menjawab Masalah Haji, Umrah dan Qurban (Nazaruddin \& Y. Sinaga, Trans.). Jakarta: Embun Publishing.

Syakrani, D. M. (2010). Re-Spritualizing Governance: Melebur kesucian Spiritual Menjadi Kemuliaan Profesional di Tempat Kerja Berdasarkan Teologi Bekerja di Surga. Yogyakarta

Triyuwono, I. (2009). Perspektif, Metodologi, dan Teori Akuntansi Syariah. Jakarta: PT Rajagrafindo Persada. 